\title{
A AUTORIDADE DO EDUCADOR NO CENÁRIO TECNOLÓGICO: INTERLOCUÇÕES FREIREANAS
}

\author{
Elaine Conte ${ }^{\mathrm{i}}$ \\ Adilson Cristiano Habowski ${ }^{\text {ii }}$
}

\begin{abstract}
Resumo: O estudo, de bases hermenêuticas, problematiza a questão da crise da autoridade do educador no cenário tecnológico, tomando como lócus investigativo a perspectiva freireana. Discutimos a questão da autoridade frente às múltiplas possibilidades de construção do conhecimento autoral na cultura digital. Em meio às contradições vigentes, trata-se de revitalizar as bases dialógicas entre autoridade e liberdade, pois é nesta tensão que se reconhecem e se retroalimentam as práticas formativas marcadas pela sensibilidade dialética e pelo respeito aos saberes pedagógicos. Há que se compreender e incorporar as novas linguagens digitais à reeducação dos conhecimentos, criando vínculos autônomos e cooperativos para fazer valer a autoridade da autocrítica e das inter-relações humanas.
\end{abstract}

Palavras-chave: Paulo Freire. Autoridade do educador. Cultura Digital.

\section{AUTHORITY OF THE EDUCATOR IN THE TECHNOLOGICAL SCENARIO: FREIREANAS INTERLOCUÇÕES}

\begin{abstract}
The study, based on hermeneutics, problematizes the issue of the crisis of the authority of the educator in the technological scene, taking the Freirean perspective as an investigative locus. We discuss the issue of authority in the face of the multiple possibilities of building authorial knowledge in digital culture. In the midst of the current contradictions, it is a matter of revitalizing the dialogical bases between authority and freedom, because it is in this tension that the formative practices marked by dialectical sensitivity and respect for pedagogical knowledges are recognized and given feedback. It is necessary to understand and incorporate the new digital languages to the reeducation of knowledge, creating autonomous and cooperative ties to assert the authority of self-criticism and human relationships.
\end{abstract}

Keywords: Paulo Freire. Authority of the educator. Digital Culture.

\section{Introdução}

Procuramos neste estudo (re)pensar a questão da autoridade do educador na cultura digital, tomando por base as leituras e o diálogo com Paulo Freire (1992, 1996, 2005, 2009). Freire elaborou os alicerces de sua práxis pedagógica interligada aos contextos sociopolíticos brasileiros, atento às dificuldades do povo, sobretudo na busca de respostas democráticas voltadas à superação de regimes autoritários e opressores. Freire oferece uma diversidade de possibilidades epistemológicas, éticas e sociopolíticas, diante de pensamentos homogeneizadores 
de cultura, que torna possível conhecer os mecanismos de poder aprisionadores da vida e o reconhecimento dos saberes necessários que desautorizam ações autoritárias. Para Freire, o ato de educar exige liberdade e autoridade (FREIRE, 2005). Nessa concepção, a autoridade pedagógica está interligada ao direito de liberdade, à autonomia, à autoria, à cooperação solidária e ao reconhecimento dos saberes socioculturais, para assim lançar perguntas, mobilizar o (re)conhecimento das diferenças e questionar a própria realidade que precisa ser reconstruída no seu contrapelo, com teor crítico-libertador e compromisso com a justiça e transformação social. (BENJAMIN, 1985; FREIRE, 1996).

Partimos da compreensão de que, com as tecnologias digitais, surgem novos diálogos interculturais e modos de aprender, reconfigurando a autoridade do educador, rompendo, de certa forma, com os modelos de educação bancária e autoritária voltados às competências operacionais e não aos saberes humanos. Nessa condição formal e de uma pedagogia autoritária que suspende o diálogo aberto,

\begin{abstract}
O educador é o que educa; os educandos os que são educados; o educador é o que sabe; os educandos os que não sabem; o educador é o que pensa; os educandos os que são pensados; o educador é o que diz a palavra; os educandos, os que as escutam docilmente; o educador é o que disciplina; os educandos, os disciplinados; o educador é o que opta e prescreve sua opção; os educandos os que seguem a prescrição; o educador é o que atua; os educandos, os que têm a ilusão de que atuam, na atuação do educador; o educador escolhe o conteúdo programático; os educandos jamais são ouvidos nesta escolha, acomodam-se a ele; o educador identifica a autoridade do saber com sua autoridade funcional, que se opõe antagonicamente à liberdade dos educandos; estes devem adaptar-se às determinações daquele; o educador, finalmente, é o sujeito do processo; os educandos, meros objetos. (FREIRE, 1996, p. 67).
\end{abstract}

Há décadas, o contexto socioeducacional é marcado pela presença das tecnologias atreladas às regras autoritárias, baseadas em finalidades de aprendizagem tecnocrática e mercantilista. Em outras palavras, as tecnologias como artefatos humanos servem para beneficiar os privilégios tradicionais, autoritarismos, ou seja, elas abdicam do compromisso com a democracia, com os marginalizados e com o movimento de solidariedade por iguais oportunidades. Daí a necessidade de desenvolver uma prática de liberdade frente ao quadro atual de relações por competências operacionais e de (auto)exclusões globais, para superar a tradição autoritária de interesses capitalistas, orientando-se para a responsabilidade, a tomada de posição, a reelaboração dos saberes e dos processos formativos. Faz parte do processo de ensinar e de aprender exercer a autoridade, tornar o sujeito responsável e autônomo por suas ações. Na verdade, a autonomia surge das múltiplas experiências culturais e da responsabilidade que vamos assumindo ao logo da vida, estando assim, na contramão de autoritarismos pedagógicos unidirecionais.

Revista Interinstitucional Artes de Educar. Rio de Janeiro, V. 4 N. 2 - pag 406-425 (mai - ago 2018): "Dossiê 50 anos da Pedagogia do Oprimido: movimentos de opressões e emancipações contemporâneas na América Latina e África" 
Compreender a autoridade do educador é fundamental para o desenvolvimento dos processos formativos de conquista da humanidade com as tecnologias digitais, pois se desdobra na perspectiva de estranhar, desconfiar e questionar as informações aparentes, instigando para indagações que visem desbanalizar o cotidiano como um projeto social. Diante disso, lançamos a seguinte problemática: de que forma renovar a autoridade do educador em termos de (re)construção de conhecimento no universo digital, tendo por base a pedagogia freireana? Esta pesquisa tem seu alicerce na abordagem hermenêutica adorniana, pressupondo tecer diálogos tensos com a totalidade de significados vitais, na busca de sentidos para as incoerências e incompletudes visíveis. Theunissen (1983, p. 44) afirma que o desvelamento da sociedade pela dialética de Adorno (1966) constitui-se em "evidenciar o divergente, o dissonante, aquilo que é contrário a uma possibilidade de verdadeira consciência e de autonomia do homem sobre o seu destino" [e é] "ao mesmo tempo a possibilidade de contrapor-se ao estabelecido, de negá-lo com a intenção de construir outra situação social”. Nessa perspectiva, trata-se de pensar por contradição a questão da autoridade pedagógica e de elaborar uma proposta formativa em que as perplexidades e adversidades do mundo danificado e da práxis educativa possam produzir metamorfoses de resistência sociopolítica, apontando possibilidades de pensar, aprender, sentir e agir em tempos de cultura digital.

As relações de ensino e de aprendizagem no contexto na cultura digital confluem para um processo hermenêutico, no sentido de estabelecer novas relações da autoridade entre os conteúdos culturais aparentes e os modos de interagir no mundo, visando uma atualização dos modos de comunicação que são capazes de problematizar e desmitificar os conceitos e suas relações. "A atitude hermenêutica desperta diferentes visões e discursos de mundo como questões inspiradoras e inquietantes para continuar o diálogo educativo com as diferenças e a pluralidade de formas de pensar, sentir e agir no mundo". (HABOWSKI; CONTE; PUGENS, 2018 , p. 183). Há, portanto, que compreender a autoridade do educador na cultura digital para o desenvolvimento dos processos formativos de bases dialógicas, sem o autoritarismo de que o professor tenha sempre a última palavra, convidando para indagações sobre os conhecimentos que estão se (re)configurando com as ressonâncias das tecnologias digitais. Cabe lembrar que,

Ensinar exige respeito à autonomia do ser educando. [...] Saber que devo respeito à autonomia, à dignidade e à identidade do educando e, na prática, procurar a coerência com este saber, me leva inapelavelmente à criação de algumas virtudes ou qualidades sem as quais aquele saber vira inautêntico, palavreado vazio e vontade arrogante do mestre (FREIRE, 2005, p. 65-69). 
Tais perspectivas compõem as dimensões básicas da interação e da ação pedagógica que não se limitam a considerações objetivas e resolutivas, mas abrem outros sentidos e linguagens articulados pela capacidade de reflexão, já que o conhecimento é fruto de uma tensão que movimenta e transforma as visões dos sujeitos, bem como de formas de autoridade para resistir aos dispositivos de poder coercitivo nas práticas pedagógicas. A busca de sentido das tecnologias na educação é um esforço hermenêutico cujo propósito é problematizar a questão da autoridade do educador na cultura digital, que é uma condição histórico-cultural de ensinar e de aprender numa relação de interdependência formativa. Para Libâneo (1994, p. 251),

\begin{abstract}
$\mathrm{Na}$ sala de aula o professor exerce uma autoridade, fruto de qualidades intelectuais, morais e técnicas. Ela é um atributo da condição profissional do professor e é exercida como um estímulo e ajuda para o desenvolvimento independente dos alunos. [...] A autoridade deve fecundar a relação educativa e não cerceá-la. Autoridade e autonomia são dois polos do processo pedagógico. A autoridade do professor e a autonomia dos alunos são realidades aparentemente contraditórias mas, de fato, complementares. O professor representa a sociedade, exercendo um papel de mediação entre o indivíduo e a sociedade. O aluno traz consigo a sua individualidade e liberdade. Entretanto, a liberdade individual está condicionada pelas exigências grupais e pelas exigências da situação pedagógica, implicando a responsabilidade. Nesse sentido, a liberdade é o fundamento da autoridade e a responsabilidade é a síntese da autoridade e da liberdade.
\end{abstract}

Esta perspectiva mostra que a autoridade do educador é uma atividade pedagógica básica que surge do diálogo da vida democrática na cultura digital, cujas noções de disciplina, limite, autoria, ganham sentido nas dimensões do ensinar a pensar e do aprender a agir nos contextos socioeducacionais. Tal noção que se realiza mediante ações humanas e decisões faz parte do cotidiano das relações pedagógicas e implica autoridade epistemológica para formar as novas gerações livres porque autônomas e, ao mesmo tempo, gerir e engajar as novidades da sociedade digital para problematizar a práxis socioeducacional garantindo condições para que todos possam dizer a palavra e participar de ações coletivas qualificadoras da vida. Para desenvolvermos esta ideia, o estudo apresenta inicialmente as lutas, os exílios e a pedagogia de Paulo Freire. Em seguida, dialogamos sobre a questão da autoridade do educador na cultura digital por meio de interlocutores como Zuin e Zuin (2011), Zuin (2015), Libâneo (1994), Saviani (2007), Türcke (2010) entre outros pensadores. E, por fim, as considerações finais que justificam essa discussão na atualidade.

\title{
A Pedagogia de Paulo Freire
}

Revista Interinstitucional Artes de Educar. Rio de Janeiro, V. 4 N. 2 - pag 406-425 (mai - ago 2018): "Dossiê 50 anos da Pedagogia do Oprimido: movimentos de opressões e emancipações contemporâneas na América Latina e África" DOI:10.12957/riae.2018.38035 
Paulo Freire (1921-1997) é o Patrono da Educação Brasileira desde 2012. Destacou-se por manter viva uma utopia pedagógica e política de emancipação dos oprimidos por meio da autonomia, da conscientização, do diálogo libertador capaz de transformar o mundo. Freire desenvolveu seus trabalhos iniciais voltados à alfabetização de adultos, mas, posteriormente, debruçou-se à valorização dos saberes populares, pedagógicos e culturais, examinando os desafios da autonomia e da heteronomia, opondo-se de forma crítica à educação bancária e denunciando a falta de reflexão sobre a sociedade, a ordem social e os meios - de caráter elitista, autoritário e domesticador (FREIRE, 2005). Seu trabalho intelectual em prol dos oprimidos foi obstruído pelo golpe Militar de 1964, pois a ditadura imobilizava a classe oprimida a lutar por seus direitos e a ter liberdade de expressão, por mecanismos de perversão social e de exclusão. De acordo com Freire e Shor (1996, p. 31), “uma pedagogia autoritária, ou um regime político autoritário, não permite a liberdade necessária à criatividade, e é preciso criatividade para se aprender".

Paulo Freire foi um dos educadores críticos de vertente marxista, que após algumas prisões porque estava preocupado em desenvolver um programa de alfabetização de adultos para o país não teve outra alternativa a não ser o exílio, pois era considerado um perigoso subversivo internacional, um inimigo do povo brasileiro. $\mathrm{O}$ exílio não ocasiona um mero afastamento do sujeito da realidade primeira, mas também o coloca em pleno contato com a nova realidade a qual ele passa a se inserir, com fé e esperança na bondade humana em seu sentido mais genuíno. "Nós somos seres indiscutivelmente programados mas, de modo nenhum, determinados. Somos programados sobretudo para aprender... É precisamente porque nos tornamos capazes de inventar nossa existência”. (FREIRE, 2005, p. 126). A Ditadura Militar no Brasil caracterizou-se pela ausência de democracia, destruição dos direitos constitucionais, censuras, perseguições políticas e sentenças aos que eram contrários à ditadura, deixando marcas e estragos no sistema educacional e na história nacional. Tudo indica que a sociedade capitalista brasileira ainda é,

[...] fechada a que já nos referimos. Sociedade, acrescente-se, com o centro de decisão de sua economia fora dela. Economia, por isso mesmo, comandada por um mercado externo. Exportadora de matérias primas. Crescendo para fora. Predatória. Sociedade reflexa na sua economia. Por isso alienada. Objeto e não sujeito de si mesma. Sem povo. Antidialogal, dificultando a mobilidade social vertical ascendente. Sem vida urbana ou com precária vida urbana. Com alarmantes índices de analfabetismo, ainda hoje persistentes. Atrasada. Comandada por uma elite superposta a seu mundo, ao invés de com ele integrada. (FREIRE, 2009, p. 57).

O exílio marcou profundamente Freire em suas reflexões, descobertas, compreensões, dificuldades vividas e experiências intelectuais e emocionais, tornando a obra mais engajada, 
questionadora e crítica da realidade. As críticas e manifestações de Freire adquiriram consistência na medida em que esteve inserido nos contextos de expatriação. Por isso, publicou diversas obras que refletiam suas experiências no Brasil e suas vivências nômades de exilado político. Da vivência comprometida com os oprimidos, Freire construiu suas reflexões percebendo as incoerências e obstáculos do processo emancipador e os mecanismos autoritários e de poder usados para manter a opressão em relação aos dominados. Freire provocou hipóteses transformadoras sobre a práxis social crítica mediada pelo diálogo, articulando as dimensões objetiva, subjetiva e social da racionalidade educativa, pela capacidade de leitura crítica de mundos.

A Pedagogia do oprimido está voltada para uma vida com resistência aos totalitarismos e que necessita tomar consciência das relações sociais de poder, para que o sujeito torne-se autor de sua própria história, realizando ações gestadas no direito de liberdade. Trata-se de um processo de humanização daquele excluído para que possa ser o um sujeito autônomo e de discurso crítico. Para Freire (1992, p. 90),

[...] o oprimido, libertando-se, liberta o opressor, o não haver, como antes sublinhei, declarado que a luta de classes é o motor da história, o tratamento que eu dava ao indivíduo, sem aceitar reduzi-lo a puro reflexo das estruturas socioeconômicas, o tratamento que dava à consciência, à importância da subjetividade, o papel da conscientização que, na Pedagogia do oprimido, supera, em termos de criticidade, o a ela atribuído em Educação como prática da liberdade.

Através da pedagogia do oprimido apresenta-se um novo entendimento de educação na tentativa de resistir às visões hegemônicas do mundo da cultura, das relações de ensino e de aprendizagem e da relação educador e educando. A expressão educação bancária, que faz menção à estrutura administrada e estabilizada de banco, fazendo críticas a um modelo educacional que percebe o educando como um receptor passivo nos processos pedagógicos, e o educador depositante de saberes prontos, hierárquicos, autoritários, abstratos e opressores. A pedagogia do oprimido na crítica à educação bancária consiste em tornar o educando partícipe dos processos de aprendizagem, capaz de (re)conhecer e (re)elaborar saberes em diálogo com os outros. Uma pedagogia que gera a libertação do oprimido para o conhecimento crítico do mundo, marcado pela autonomia de ir contra as opressões totalitárias e permitindo ao educando um engajamento e participação social, na expressão de opiniões e de fazer questionamentos, esclarecendo ao educando o conhecimento de seus direitos e de sua posição na sociedade enquanto cidadão ativo nas deliberações sociais. Trata-se de uma ação conjunta entre educador e educando para uma transformação dos contextos sociais de dominação que acontecem por meio 
de relações individualistas, egoístas e competitivas de códigos capitalistas. Para Freire, não existe emancipação individual, de um pensar solitário, arbitrário e dominado por particularismos, visto que a dimensão da emancipação só tem sentido e validade na realização coletiva.

O professor que desrespeita a curiosidade do educando, o seu gosto estético, a sua inquietude, a sua linguagem, mais precisamente, a sua sintaxe e a sua prosódia; o professor que ironiza o aluno, que o minimiza, que manda que ele se ponha no seu lugar ao mais tênue sinal de sua rebeldia legítima, tanto quanto o professor que se exime do cumprimento de seu dever de propor limites à liberdade do aluno, que se furta ao dever de ensinar, de estar respeitosamente presente à experiência formadora do educando, transgride princípios fundamentalmente éticos de nossa existência. É neste sentido que o professor autoritário, que por isso afoga a liberdade do educando, amesquinhando o seu direito de estar sendo curioso e inquieto, tanto quanto o professor licencioso rompe com a radicalidade do ser humano - a de sua inconclusão assumida em que se enraíza a eticidade. (FREIRE, 2005, p. 66-67).

Freire dedicou grande parte de sua vida ao reconhecimento da educação que desvela o mundo pelo diálogo, questiona e valoriza as diferenças em uma sociedade emancipada, bem como no combate às formas de pedagogia bancária, excludentes e elitistas. Freire expõe que é necessário aumentar o grau de atuação política da população sobre as questões que acontecem no âmbito social enquanto sujeitos voltados para a construção emancipatória. Para isso, sugere como potencial o círculo de cultura validado na palavra que circula nos grupos, pois em cada âmbito social existem temas geradores para serem discutidos, destacando-se a compreensão pela leitura crítica e interação com os clássicos, não como simples repetição, mas como participação no presente, alargando horizontes de conhecimento do período histórico e dos contextos. Os círculos de cultura eram realizados por investigações através de temas geradores com conversas informais com os moradores da localidade, em que "dirão o porquê, e como e o para que da investigação que pretendem realizar e que não podem fazê-lo se não se estabelece uma relação de simpatia e confiança mútuas”. (FREIRE, 1996, p. 121). Os pesquisadores em diálogos com a população acionam um olhar crítico, recolhendo subsídios para a compreensão dos modos de vida, de ser e de pensar dos sujeitos, a fim de que juntos possam tecer a sua decodificação, através de uma visão reflexiva, questionadora, relacional e observadora da própria realidade.

Pela via do diálogo intercultural Freire conseguiu (re)aprender, questionar e dizer a própria palavra, pois "foi por esses pedaços de mundo, como exilado, que pude compreender melhor o meu próprio país. Foi vendo-o de longe, foi tomando distância dele que eu entendi melhor a mim mesmo". (FREIRE; FAUNDEZ, 1985, p. 22). Freire (1996, p. 38) acrescenta que é a "reflexão e a ação dos homens sobre o mundo que faz a transformação acontecer, sem esses dois atos a superação da condição opressor e oprimido é impossível”. O pensador destaca que não existe diálogo sem a amorosidade do falar e do ouvir o outro, visto que é da linguagem que 
nasce o saber desafiador da capacidade de decodificar e examinar os fatos do mundo de forma aventureira e investigativa. Assim, "se não amo o mundo, se não amo a vida, se não amo os homens, não me é possível o diálogo". (FREIRE, 1996, p. 92). Para o diálogo acontecer é necessário despertar e potencializar nos sujeitos a capacidade de (re)inventar-se na escuta sensível como um artifício constituinte antes de qualquer diálogo, pois o sujeito educa-se com o outro. Como apresenta Freire (1996, p. 94), "ao fundar-se no amor, na humildade, na fé, nos homens, o diálogo se faz uma relação horizontal, em que a confiança de um polo no outro é consequência óbvia. Seria uma contradição se, amoroso, humilde e cheio de fé, o diálogo não provocasse este clima de confiança entre seus sujeitos".

Na concepção de Freire, é por meio da relação dialógica que se inicia o processo de ensinar e de aprender com atividades participativas de pesquisa e de (re)elaboração própria e coletiva, nas quais podemos ser autônomos e motivados a (re)conhecer ações, interpretações enquanto colaboradores do pensar social. Nesse processo educativo e formativo, a autonomia é quem possibilita esse crescimento emancipatório pela interdependência humana e capacidade de (auto)crítica, para o desenvolvimento do gosto estético de fazer leituras e interpretações nas relações solidárias com os outros no mundo da vida. Contudo, esse diálogo não pode reduzir-se a uma postura de impor ideias autoritariamente ou simplesmente trocá-las, ou seja, "o diálogo não pode converter-se num bate-papo desobrigado que marche ao gosto do acaso entre professor ou professora e educandos. O diálogo pedagógico implica tanto o conteúdo ou objeto cognoscível”. (FREIRE, 1992, p. 118).

Mas não é possível uma "educação problematizadora, que rompe com os esquemas verticais característicos da educação bancária, realizar-se como prática da liberdade, sem superar a contradição entre o educador e os educandos. Como também não lhe seria possível fazê-lo fora do diálogo". (FREIRE, 1996, p. 95). Então, o diálogo surge do encontro com o outro, com o estranho, enquanto encontro de alteridades na conversação coletiva. $\mathrm{O}$ diálogo tem algo de libertador e contribui para a emancipação na interdependência do agir. A educação contribui para a formação de sujeitos críticos, pensantes, pois instiga a questionar o mundo, perceber a condição humana de inacabamento e de necessidade de buscar a melhoria da vida social. É o sujeito crítico, portanto, que será protagonista das mudanças no mundo, pois ao aperfeiçoar sua criticidade deixa de ser um indivíduo isolado e semiformado, passando a ser um agente questionador das desigualdades na sociedade, já que percebe sua condição no movimento formativo de afastar-se de si para se engajar no mundo coletivo, que ganha sentido emancipatório a partir do outro. Dessa forma, Freire (1996) desenvolve uma pedagogia social e crítica, contribuindo para os processos de desalienação intersubjetiva. 
Deste modo, o educador problematizador refaz, constantemente, seu ato cognoscente, na cognoscitividade dos educandos. Estes, em lugar de serem recipientes dóceis de depósitos, são agora investigadores críticos, em diálogo com o educador, investigador crítico também. Quanto mais se problematizam os educandos, como seres no mundo e com o mundo, tanto mais se sentirão desafiados. Tão mais desafiados, quanto mais obrigados a responder ao desafio. Desafiados, compreendem o desafio na própria ação de captá-lo. Mas precisamente porque captam o desafio como um problema em suas conexões com outros, num plano de totalidade e não como algo petrificado, a compreensão resultante tende a tornar-se crescentemente crítica, por isto, cada vez mais desalienada. (FREIRE, 1996, p. 97- 98).

O diálogo passa pela condição humana e abre possibilidades para a utopia esperançosa, visto que não há diálogo sem a esperança que acompanha a busca de mudanças para a melhoria da vida em sociedade. Nas palavras de Freire (1996, p. 95), “[...] movo-me na esperança enquanto luto e, se luto com esperança, espero [...]", não de forma ilusória, pacífica e receptora, mas com a disposição de saber debater proposições e reconstruí-las permanentemente conforme as necessidades. É por meio da geração de uma reflexividade com o outro, que nutrimos o diálogo e o pensar verdadeiro. A capacidade de diálogo é a abertura ao olhar do outro, à inquietação e à curiosidade de aprender e evoluir com o outro, indo além da uniformização, de experiências de exclusão social ou homogeneização das consciências, "porque os sujeitos dialógicos não apenas conservam sua identidade, mas a defendem e assim crescem um com o outro. O diálogo, por isso mesmo, não nivela, não reduz um ao outro. Nem é favor que um faz ao outro". (FREIRE, 1992, p. 118).

Freire (2005) destaca que a prática pedagógica desenvolvida sob a perspectiva crítica e participativa, de sujeitos dialogantes na vida social, envolve o movimento de pensar vinculado ao outro e aos processos de ensino e de aprendizagem, como um ato educativo transformador do mundo. Tal movimento dialético consiste na transformação de si no contato com o outro, para aprender com o diferente enquanto um processo de renovação das próprias aprendizagens no (re)conhecimento do outro. (JACOBI; HABOWSKI; CONTE, 2018). Uma educação através do diálogo com as tecnologias digitais requer uma visão humanista e crítica que é tecida em conjunto, para que se possa (re)construir saberes culturais, conforme as necessidades percebidas para reaviar ações conjuntas que conduzam a um mundo mais justo e equânime, diante dos progressos e retrocessos da autoridade.

\section{Autoridade pedagógica versus cultura digital}


A autoridade do educador sob a perspectiva de Freire é trabalhada pela lógica emancipatória do inacabamento humano, no direito à liberdade e autonomia, em que a reinvenção de conhecimentos é condição dialógica e cooperativa da racionalidade pedagógica. Se na educação bancária a autoridade do educador acontecia por meio da submissão, conforme as regras constituídas pela direção escolar e pelo educador em sala de aula, também era fortalecida pelas estruturas constitutivas do mundo social e das práticas culturais. No entanto, com as mudanças nos modos de ensinar e aprender em meio às transformações da cultura digital surgem perspectivas renovadas para as práticas pedagógicas em sala de aula, fazendo com que o entendimento de autoridade do educador seja ressignificada. A autoridade do educador, assim como os saberes disciplinares da escola estão em crise e abalados pela instabilidade dos tempos de dispersão e presença da cultura digital, causando o comprometimento das possibilidades de (re)construção dialógica dos conhecimentos.

Não obstante, uma situação dialógica implica a ausência do autoritarismo. O diálogo significa uma tensão permanente entre a autoridade e a liberdade. Mas, nessa tensão, a autoridade continua sendo, porque ela tem autoridade em permitir que surjam as liberdades dos alunos, as quais crescem e amadurecem, precisamente porque a autoridade e a liberdade aprendem a autodisciplina. (FREIRE; SHOR, 1996, p. 127).

Freire entende que ser professor implica torna-se parte da própria natureza educativa sendo capaz de estimular a autonomia, a autodisciplina e o pensamento crítico dos educandos, exercendo nos processos de ensino e de aprendizagem a coordenação de ideias e ações, instigando e provocando a curiosidade, a inquietação e a problematização epistemológica. Dessa forma, a perda da autoridade pedagógica acontece quando, por exemplo, “o educador que, ensinando geografia, 'castra' a curiosidade do educando em nome da eficácia de memorização mecânica do ensino dos conteúdos, tolhe a liberdade do educando, a sua capacidade de aventurar-se". (FREIRE, 1996, p. 56). Assim sendo, "o bom professor é o que consegue, enquanto fala, trazer o aluno até a intimidade do movimento de seu pensamento. Sua aula é assim um desafio e não uma cantiga de ninar”. (FREIRE, 1996, p. 86).

Nessa perspectiva, "a autoridade do professor está sendo constantemente questionada, debatida e colocada em xeque no contexto escolar, causando preocupações, justamente porque sem autoridade não se faz educação" (ZUIN; ZUIN, 2011, p. 745). Sem sombra de dúvidas, "em tempos da disseminação da cultura digital, há modificações nucleares em relação ao conceito de autoridade pedagógica, o que acarreta alterações decisivas nas relações entre professores e alunos". (ZUIN; ZUIN, 2011, p. 45). As rupturas derivadas da cultura digital fazem com que os educadores revejam seus posicionamentos e suas práticas pedagógicas com a ideia de um progresso de dominação e competências por meios técnicos, mas sem referências aos saberes necessários à construção de relações com os seus educandos considerados nativos digitais. Tal perspectiva está em consonância com Freire (1996, p. 78) quando diz que:

Desta maneira, o educador já não é o que apenas educa, mas o que, enquanto educa, é educado, em diálogo com o educando que, ao ser educado, também educa. Ambos, assim, se tornam sujeitos do processo em que crescem juntos e em que os argumentos 
de autoridade já, não valem. Em que, para ser-se, funcionalmente, autoridade, se necessita de estar sendo com as liberdades e não contra elas. Já agora ninguém educa ninguém, como tampouco ninguém se educa a si mesmo: os homens se educam em comunhão, mediatizados pelo mundo. Mediatizados pelos objetos cognoscíveis que, na prática bancária, são possuídos pelo educador que os descreve ou os deposita nos educandos passivos.

Com isso, alteram-se os paradigmas conservadores de ensino, das hierarquias e autoritarismos dos processos de ensino e de aprendizagem, que obedecem à simples reprodução manipuladora de conteúdos. As tendências pedagógicas, conforme Saviani (2007, p. 380), pautam-se pela influência de pressupostos de determinados sistemas filosóficos:

Se na pedagogia tradicional a iniciativa cabia ao professor, que era, ao mesmo tempo, o sujeito do processo, o elemento decisivo e decisório; e se na pedagogia nova a iniciativa se desloca para o aluno, situando-se no alicerce da ação educativa na relação professoraluno, portanto, relação interpessoal, intersubjetiva; na pedagogia tecnicista o elemento principal passa a ser a organização racional dos meios, ocupando o professor e o aluno posição secundária, relegados que são à condição de executores de um processo cuja concepção, planejamento, coordenação e controle ficam a cargo de especialistas supostamente habilitados, neutros, objetivos e imparciais.

Vivenciamos sempre novos desafios para assegurar a autoridade do educador em sala de aula em meio aos artefatos tecnológicos, cuja responsabilidade e interdependência podem gerar novas potencialidades de ações democráticas e propícias à liberdade de aprender pela autonomia. A compreensão e o uso das tecnologias digitais tornam-se uma necessidade da vida em sociedade e a educação não pode negligenciar. De acordo com Zuin e Zuin (2011, p. 213), “as relações entre tais tecnologias, os professores e os processos de ensino e aprendizagem implica considerar a redefinição imagética do professor, bem como dos métodos historicamente empregados para promover a disciplina e a concentração entre os estudantes". Assim, compreendemos que a autoridade do educador no cenário tecnológico necessita não apenas da sua inserção, mas de novas compreensões formativas para a sociedade contemporânea, para decodificá-los e participar da sua (re)invenção no trabalho pedagógico.

Apesar do avanço gradual nas políticas públicas e do esforço de implantação e expansão da "inovação tecnológica" nas escolas, ainda existem grandes desigualdades sociais e a falta de sensibilidade pedagógica, pois persiste uma autoridade instrumental, que é distinta de uma autoridade (re)criadora e revisora de saberes. Na perspectiva de Zuin e Zuin (2011, p. 763), "atualmente as informações e imagens registradas pelo Google podem muito bem ser utilizadas, a qualquer momento, tanto para identificar quanto literalmente formatar um perfil, sobretudo o mercadológico, de um determinado usuário deste mecanismo de busca", mas o professor ficou refratário ao próprio Google sendo destituído de autoridade no sentido de pensar com os 
educandos sobre essas informações. No entanto, essa tendência globalizada interfere na ação pedagógica e nos conflitos sociais, no mundo digital da autoridade e do contexto em que estamos inseridos. Então, para além de privilegiar uma perspectiva utilitarista e de absolutização dos artefatos tecnológicos, precisamos considerar a intencionalidade e a autoridade do educador em movimentar esses mecanismos na prática pedagógica. Na verdade,

O conceito de autoridade pedagógica sempre esteve entre os principais temas da filosofia da educação e das práticas pedagógicas, haja vista as formas como as pedagogias tradicional, moderna e tecnicista caracterizaram a autoridade do professor. Seja ocupando ou não um papel central no desenvolvimento de tal relação, a condição do professor como modelo identitário do aluno se fundamentou na internalização e na contestação de tal figura de autoridade. A consolidação da autoridade pedagógica fundamentou-se, historicamente, sobretudo no controle disciplinar exercido pelo professor, na medida em que ele era identificado e se identificava como figura central e/ou facilitador do aprendizado dos conteúdos apresentados no transcorrer das relações estabelecidas com seus alunos. (ZUIN; ZUIN, 2011, p. 746).

A cultura digital abriu possibilidades trazendo ao sujeito o acesso a um novo espaço comunicacional, que pode ir além da condição neutra pautada em interesses técnicos, potencializando as condições de reconhecer a pluralidade das culturas e as diferentes metodologias de ensino construídas mundialmente. Daí que sem a pressuposição dialógica que está encarnada na autoridade do educador, bloqueada pela dispersão e desorientação vigente do puro domínio tecnológico, torna-se impossível ensinar e aprender o mundo.

É por isto que a verdadeira autoridade não se afirma como tal, na pura transferência, mas na delegação ou na adesão simpática. Se se gera num ato de transferência, ou de imposição antipática sobre as maiorias, se degenera em autoritarismo que esmaga as liberdades. Somente ao existenciar-se como liberdade que foi constituída em autoridade, pode evitar seu antagonismo com as liberdades. Toda hipertrofia de uma provoca a atrofia da outra. Assim como não há autoridade sem liberdade e esta sem aquela, não há autoritarismo sem negação das liberdades e licenciosidade sem negação da autoridade. $\mathrm{Na}$ teoria da ação dialógica, portanto, a organização, implicando em autoridade, não pode ser autoritária; implicando em liberdade, não pode ser licenciosa. Pelo contrário, é o momento altamente pedagógico, em que a liderança e o povo fazem juntos o aprendizado da autoridade e da liberdade verdadeiras que ambos, como um só corpo, buscam instaurar, com a transformação da realidade que os mediatiza. (FREIRE, 1996, p. 178).

A atividade pedagógica desenvolvida com autoridade diante da cultura digital não se acha excluída de cognoscibilidade, de afetividade, de metodologias rigorosas nas buscas sobre os conhecimentos escolares, enfim, o exercício da autoridade pedagógica acontece na experiência da procura, da pesquisa por referências em relação à própria prática. Nessa perspectiva, as tecnologias digitais são provocadoras de transformações nos modos de aprender e de se relacionar com os outros, alterando também a autoridade do educador em sala de aula. Tais 
transformações se refletem nos modelos de ensino, havendo uma decadência e uma espécie de crise por meio de um ensino técnico facilitado, objetivo, silenciado, neutro e permissivo. A inflexibilidade pedagógica e as cisões dialógicas de mundos não permitem realizar a guinada reconstrutiva de saberes por meio das tecnologias.

Orientar para a emancipação e manter o compromisso crítico na cultura digital faz parte da dimensão da autoridade do educador, no sentido de ampliar as relações interdisciplinares em sala de aula com as culturas e os conhecimentos do mundo hiperconectado, visando à criação de uma maior sensibilidade humana e pedagógica. As tecnologias digitais ampliaram as conversas, os vínculos comunicantes e as experiências de vida, criando colaborações e formas de participar socialmente por meio de palestras, debates em qualquer parte do mundo, sem nos deslocarmos fisicamente, acessar as informações políticas-sociais instantaneamente, além de agir e interagir e isso tudo independentemente de onde nós estamos. Tudo indica que as questões de informatização são importantes para o desenvolvimento do educador, dos educandos e para as situações de ensino e de aprendizagem.

Nas palavras de Freire (1996, p. 29), “enquanto ensino continuo buscando, reprocurando. Ensino porque busco, porque indaguei, porque indago e me indago. Pesquiso para constatar, constatando, intervenho, intervindo educo e me educo". Nessa conjuntura, é preciso um olhar crítico e questionador para repensar acerca da própria autoridade do educador, a fim de promover a autonomia dos sujeitos no mundo digital, para torná-los capazes de indagar e dialogar com as repentinas mudanças globais. Dessa forma, "ensinar não é transferir a inteligência do objeto ao educando mas instigá-lo no sentido de que, como sujeito cognoscente, se torne capaz de inteligir e comunicar o inteligido". (FREIRE, 1996, p. 119). Há uma necessidade de renovar os potenciais pedagógicos das tecnologias digitais, para prevenir posturas autoritárias que podem ser de alienação, estagnação e, principalmente, de exclusão tecnológica coletiva. "Por isto é que esta educação, em que educadores e educandos se fazem sujeitos do seu processo, superando o intelectualismo alienante, superando o autoritarismo do educador bancário, supera também a falsa consciência do mundo”. (FREIRE, 1996, p. 105).

A integração e o engajamento social das tecnologias na educação nos desafiam a rever a sua tecnicidade, característica comportamentalista de estímulo-resposta, para congregar novos sentidos para além desta ideia de identificação com a neutralidade tecnológica. Então, percebemos nas tecnologias digitais potencialidades para que as situações de perda de autoridade e falta de reconhecimento em sala de aula possam ser olhadas com outras perspectivas, mobilizando processos para enfrentar as dificuldades e conflitos entre educadores e educandos 
na experiência pedagógica. Esta precisa ser o lugar em que se dialoga, pensando em uma interação de liberdade cooperativa para o desenvolvimento de autorias coletivas e aprendentes.

As tecnologias tornam-se grandes potenciais para as relações humanas, para estimular aprendizagens evolutivas, bem como para enxergar as falsas fronteiras do conhecimento, por meio das pesquisas e da abertura aos mundos virtuais. Ao descentrar a função de autoridade do educador com as contradições presentes no mundo digital, os modos de aprender movem-se para as possibilidades de linguagem virtual como alicerce às aprendizagens sociais. Nesse viés, as relações entre educador e educandos passam por transformações radicais.

Evidentemente, a ênfase atribuída à ciência e à tecnologia reverbera a crença de que os indivíduos formados poderiam dominar, de forma absoluta, a condução de seu próprio destino. Porém, considerar a força pulsional da história presente na reorganização e reconstrução das experiências humanas significa compreender como as atuais relações de produção determinam a transformação da tecnologia em seu próprio fetiche. É nessa sociedade que as relações entre professores e alunos se transformam de modo radical, o que implica refletir sobre as modificações estruturais referentes à concepção de autoridade pedagógica. (ZUIN; ZUIN, 2011, p. 755-756).

As tecnologias digitais contribuem para o ensino de forma mais dinâmica e prazerosa, uma vez que tendem a favorecer as relações com os contextos socioculturais. As tecnologias abrem para os educadores e educandos novas perspectivas de entendimento em relação ao objeto de estudo, na medida em que se torna mais próxima da realidade. Nos contextos de inclusão digital é importante uma apropriação das tecnologias nas escolas e uma efetiva formação crítica dos educadores e educandos em relação às mídias digitais em suas possibilidades, ilusões fetichistas e distorções. Por isso, torna-se fundamental aprender a repensar e antecipar as demandas profissionais de autoridade e de autoria diante da conectividade ilimitada entre as diferenças. $\mathrm{O}$ acesso às tecnologias acaba disponibilizando uma pluralidade de acessos aos conhecimentos, além de múltiplos contextos, que podem servir de pretexto para aprender a exercitar a conversação coletiva, de maneira reconstrutiva, no sentido de desafiar o outro a intervir de modo crítico, criativo e participativo na realidade. Türcke (2010, p. 266) esclarece que,

Diante da atual propagação de quantidades incomensuráveis de informações transmitidas pela Internet, desenvolve-se outro fenômeno que se relaciona diretamente não só com a produção e reprodução do conhecimento, como também com a própria autoridade pedagógica: trata-se da chamada distração concentrada. Por meio do acesso a determinada informação nas redes sociais, nossa capacidade de atenção é canalizada para logo em seguida ser triturada através do acesso a outros links, outras ligações, de tal maneira que o meio de concentração se torna o próprio meio de decomposição. 
Neste contexto, a autoridade do educador muitas vezes cai em descrédito porque dispensa as correções necessárias para que o educando seja ativo no processo de aprendizagem, criando-se um afrouxamento da identidade e da autoria do educando, essenciais para que saiba orientar-se à criação coletiva. Os educadores se sentem constrangidos e intimidados pelos educandos na falta de metodologias e estratégias reconstrutivas com as tecnologias em sala de aula, surgindo aí tensões e relações de poder entre educador e educando, que só podem ser resolvidas por saberes dialógicos e buscas coletivas. A liberdade dos educandos está condicionada pelas exigências da própria escola, mas é essencial para o exercício da autoria, da responsabilidade e da reconstrução dos saberes coletivos de abertura para o diálogo. Para Freire (1996, p. 67),

\begin{abstract}
A teoria dialógica da ação nega o autoritarismo como nega a licenciosidade. E, ao fazêlo, afirma a autoridade e a liberdade. Reconhece que, se não há liberdade sem autoridade, não há também esta sem aquela. A fonte geradora, constituinte da autoridade autêntica está na liberdade que, em certo momento se faz autoridade. Toda liberdade contém em si a possibilidade de vir a ser, em circunstâncias especiais, (e em níveis existenciais diferentes), autoridades. Não podemos olhá-las isoladamente, mas em suas relações, não necessariamente antagônicas.
\end{abstract}

O desafio da autoridade do educador em tempos digitais passa por uma reeducação construída na interdependência comunicativa, que vai além do saber dominar os artefatos tecnológicos, no que tange a precisão, rapidez, sistematização, desempenho e ritmo de trabalho, pois os artefatos não podem ter um fim em si, atrapalhando o trabalho pedagógico ou ainda servindo para disputa ou distorção da própria reflexão. Zuin e Zuin (2011, p.764-765) argumentam que,

\begin{abstract}
é interessante observar o modo como em vários cursos de educação a distância os alunos são praticamente abandonados pelos professores responsáveis pelas respectivas matérias, sendo que estes docentes justificam tal atitude em nome do incentivo à chamada autonomia do aluno. Não por acaso, estes mesmos alunos muitas vezes são respaldados pelos docentes e tutores a realizar a bricolagem de textos anteriormente mencionada. É verdade que o estímulo à produção e reprodução da bricolagem é uma característica do modo como a cultura digital se estrutura por meio do ethos maquinoinstrumental, mas se a escola for considerada como espaço de reflexão crítica, então os próprios professores poderiam dialogar com seus alunos para que os textos fossem produzidos de acordo com o desenvolvimento dos próprios raciocínios. Ou seja, seria possível fazer com que a facilidade de acesso à quantidade infinita de informações proporcionasse a elaboração de reflexões críticas, e não apenas reflexos decorrentes da justaposição destas mesmas informações em textos bricolados. Por outro lado, os próprios alunos de cursos a distância muitas vezes manifestam sua satisfação em poder se afastar presencialmente do professor.
\end{abstract}

A autoridade do educador na cultura digital não pode ser pretexto para abrir mão de ensinar o educando a pensar por conta própria e formar-se, justificando que ele precisa aprender a agir exclusivamente por conta própria. A autoridade do educador gira em torno de ser um 
provocador, um articulador, que reconhece e respeita o outro, em busca de seu crescimento evolutivo, de modo a se tornar autor do seu próprio desenvolvimento em interdependência com os outros por meio do dialógico emancipador. Isso porque "não há ignorantes absolutos, nem sábios absolutos: há homens que, em comunhão, buscam saber mais”. (FREIRE, 1996, p. 95).

Para tanto, a autoridade do educador não implica em exercer um poder coercivo sobre o educando, mas de reconhecer e ser reconhecido como sujeitos de possibilidades no mundo e em interação com os outros, oportunizando aprendizagens socioculturais e abertas às tradições, às experiências distintas e às ações transformadoras dos sujeitos. Se já não temos um monopólio ou posse do saber nas formas de ensinar e de aprender na cultura digital, trata-se agora de desenvolver e explorar as ligações e correlações para a aprendizagem de (re)criação coletiva, "que movimenta lugares antes hierarquizados, para aprender no compartilhamento de conhecimentos, de percepções, de diferenças e de mundos". (MACHADO; HABOWSKI; CONTE, 2017, p. 697). A autoridade do educador não advém de uma ação centralizadora, autoritária e utilitarista do saber, mas de uma perspectiva do direito à liberdade de aprender, que traz as contradições presentes no analfabetismo digital, para mover-se rumo às aprendizagens sociais no restabelecimento da confiança, da autoria e da criatividade coletiva. Nos contextos educacionais,

\footnotetext{
as interpretações generalizantes, superficiais e fragmentadas de provas, por exemplo, forçam uma educação domesticadora e empobrecida dos processos educativos, pois a descrição de respostas prontas inviabiliza os processos de historicidade e interdependência, do que depende a ação criativa. Tudo indica que a educação criativa estaria voltada para o (re)aprender constante por ações cooperativas de estudo e aprofundamento acerca dos potenciais e metodologias com as tecnologias educacionais, para resolver os questionamentos existentes na própria realidade. (HABOWSKI; CONTE, 2018, p. 6).
}

Contudo, é necessário refletir sobre a multiplicidade dos artefatos tecnológicos nas escolas para a reconstrução de condições que estimulem e inspirem novas formas de criatividade e (re)criação cooperativa de conhecimentos no campo da educação. "No fundo, o educador que respeita a leitura de mundo do educando reconhece a historicidade do saber, o caráter histórico da curiosidade, recusando a arrogância cientificista, assume a humildade crítica, própria da posição verdadeiramente científica”. (FREIRE, 1996, p. 123). A autoridade na educação implica liberdade cooperativa pela comunicação cultural de saberes e valores intergeracionais e interculturais, sendo uma das condições para despertar aprendizagens sempre renovadas.

Em tempos nos quais os aparelhos celulares, computadores e câmeras são cada vez mais utilizados tanto dentro como fora das escolas, apresentam-se as seguintes questões: 1) 
Em meio ao acesso online de informações que podem ser obtidas em quaisquer tempos e espaços, o professor ainda poderia ser identificado como modelo identitário por parte dos alunos? 2) De que modo o professor poderia auxiliar o desenvolvimento da capacidade de concentração e da memorização de conteúdos por parte dos alunos, principalmente na sociedade na qual ocorre o bombardeamento constante de estímulos audiovisuais? e 3) De que forma o conceito de autoridade pedagógica poderia ser ressignificado no contexto histórico da denominada cultura digital? (ZUIN; ZUIN, 2011, p. 747).

A autoridade também está relacionada à posse do saber e ao poder coercitivo das proibições quando esta tem por finalidade dominar e boicotar a autonomia necessária ao reconhecimento do outro. Evidentemente que o fator que retroalimenta a autoridade é o sentimento de respeito e confiança na outra pessoa. Ora, uma figura de autoridade pode conduzir os sujeitos e coagi-las ou obrigá-los a produzir coisas impensadas, acabando por interferir decisivamente na conduta de quem fica subjugado. Dessa forma, a autoridade pode ser concebida por um sujeito que detém força e poder e usa tais mecanismos para ludibriar as demais pessoas para que obedeçam ou sigam seus preceitos, não por uma liderança relacional, interdependente e reflexiva, mas por subordinação.

Saber ensinar na cultura digital e em meio às pressões por desempenho institucional causa receio ao professor em termos de autoridade diante das tecnologias digitais por temer a competição, e inclusive os dilemas éticos dos fóruns de discussão. Dessa forma, os educandos que são nativos digitais ficam desmotivados com um ensino centralizado nos saberes apenas do educador, de uma pedagogia bancária, aguardando inquietos pela utilização das novas tecnologias como parte do aprender em sala de aula. A sociedade digital se apresenta como uma das grandes problemáticas a serem aprofundadas na área da educação, visto que experimentamos um enfrentamento entre gerações, em que a autoridade do educador é questionada em nome de uma tecnicidade irrefletida, na tentativa de centrar os processos de ensino em máquinas como elementos contemplativos ou dispersivos na sala de aula. E o mercado educacional torna o próprio professor uma máquina de ensinar, refém de um sistema administrado e comercial que aniquila a reflexão sobre a historicidade humana.

Os processos de ensino e de aprendizagem se conjecturam num esforço coletivo de educar-se e forma-se, numa abertura dialética à pesquisa e ao pensamento conjunto em busca de entendimento acerca dos conhecimentos, cuja autoridade do professor seja considerada pelos estudantes. Nessa perspectiva, a autoridade do educador precisa ser coerentemente democrática, aquela que considera as origens do educando para promover experiências e promover diálogos emancipadores. Nas palavras de Freire (1996, p. 113), "se, na verdade, o sonho que nos anima é democrático e solidário, não é falando aos outros, de cima para baixo, sobretudo, como se 
fôssemos os portadores da verdade a ser transmitida aos demais, que aprendemos a escutar, mas é escutando que aprendemos a falar com eles". A educação democrática demanda o empenho do educador em manter a coerência entre seus discursos ético-pedagógicos e suas práticas autocríticas, transformando os saberes de mundo em possibilidades autônomas de saber-se inacabado. "No fundo, o essencial nas relações entre educador e educando, entre autoridade e liberdades, entre pais, mães, filhos e filhas é a reinvenção do ser humano no aprendizado de sua autonomia”. (FREIRE, 2005, p. 105).

\section{Considerações finais}

Com base em Freire e em diálogos com outros pensadores mencionados, compreendemos que o papel do educador no contexto digital é de instigar a liberdade, a autonomia e a curiosidade epistemológica dos educandos, para despertar a problematicidade, a autocrítica e a revitalização constante frente aos movimentos culturais contemporâneas. Para tanto, o educador precisa reconhecer os conhecimentos prévios dos educandos que podem ser questionados por meio da interação humana, além de explorar a cultura digital como artifício cognitivo e afetivo de retomada da própria autoridade do educador à construção dos processos de ensinar e de aprender com o cultivo do saber tecnológico.

A compreensão relacional e reflexiva das tecnologias em sala de aula é um meio para desafiar os processos de ensino ao pensar cooperativo e dialógico, incidindo em novas condições de reconhecimento da autoridade do educador na cultura digital. Trata-se de uma leitura das tecnologias digitais como espaço à promoção e estímulo à alfabetização cognitiva, emocional e crítica dos sujeitos, pensando numa autoridade do educador que promova autores e artífices da produção de conhecimento, para a conscientização política, sociológica, reflexiva e crítica da realidade, ressignificando e reavivando os conhecimentos tradicionais. Afinal de contas, a educação crítica que visa a educação democrática e libertadora não pode ficar indiferente ao processo de aprendizado social, que ocorre em meio às relações tecnológicas e dialógicas cotidianas. Daí que uma educação coletiva e de diálogo horizontal com o mundo tecnológico precisa manter abertos os canais de comunicação para outros mundos possíveis, com novas metodologias e ações formativas.

Evidentemente, a problematização em torno da questão da autoridade do educador na cultura digital indicou que é fundamental o preparo científico e pedagógico para democratizar o acesso à informação em sala de aula, para aprender a conviver com o diferente e o desconhecido de uma formação cultural autônoma, flexível, social e de autoria coletiva. A autoridade por meio 
de coações não é reconhecida em termos de potencialidade cooperativa o que causa empobrecimento das práticas educativas, que se propagam por frágeis dispositivos de autoridade estreita e compatível com o treinamento de um campo da verdade e do saber desarticulado.

A educação na cultura digital precisa estar aberta para repensar e (re)aprender como condição ao questionamento sobre os paradoxos da realidade, além de estar em sintonia com a pluralidade da cultura digital que provoca a autorreflexão em torno dos problemas de nossa tarefa docente. Talvez a autoridade do educador deva encontrar o seu caminho na resistência à opacidade do ensino e ao silêncio em relação às tecnologias digitais como condição implícita a uma sociedade autônoma e autocrítica da própria tradição cultural. Em vez de tomadas como práticas racionais e objetivas, as tecnologias digitais passam a ser repensadas nos processos de ensino como possibilidades de realizar experiências reflexivas, de resistência crítica e de compreensão das multiculturas e diversidades, que são consideradas as bases pedagógicas e os alicerces para práticas reconhecidamente curiosas e formadoras.

\section{Referências}

ADORNO, Theodor Dialética negativa. Rio de Janeiro: Jorge Zahar, 1966.

BENJAMIN, Walter. Obras Escolhidas: magia e técnica, arte e política - ensaios sobre literatura e história da cultura. Vol. 1. Trad. Sérgio Paulo Rouanet. São Paulo: Brasiliense, 1985. p. 222232.

FREIRE, Paulo. Pedagogia da Esperança: um reencontro com a Pedagogia do Oprimido. 11. ed. São Paulo: Paz e Terra, 1992. . Pedagogia do oprimido. 36. ed. Rio de Janeiro: Paz e Terra, 1996. . Pedagogia da autonomia: saberes necessários à prática educativa. 33. ed. São Paulo: Paz e Terra, 2005. . Educação como prática da liberdade. Rio de Janeiro: Paz e Terra, 2009.

FREIRE, P.; FAUNDEZ, A. Por uma pedagogia da pergunta. Rio de Janeiro: Paz e Terra, 1985. FREIRE, P.; SHOR, I. Medo e ousadia: cotidiano do professor. 5. ed. São Paulo: Paz e Terra, 1996.

HABOWSKI, Adilson Cristiano; CONTE, Elaine; PUGENS, Natália Borba. A perspectiva da alteridade na educação. Conjectura: Filos. Educ., Caxias do Sul, v. 23, n. 1, p. 179-197, jan./abr. 2018. Disponível em: <http://www.ucs.br/etc/revistas/index.php/conjectura/article/viewFile/5541/pdf> Acesso em: 29 maio 2018. 
HABOWSKI, Adilson Cristiano; CONTE, Elaine. O ócio criativo e a educação para o século XXI. Artefactum - Revista de Estudos em Linguagem e Tecnologia. Ano X, n. 1, p. 1-15, 2018. Disponível em: <http://artefactum.rafrom.com.br/index.php/artefactum/article/view/1599/756> Acesso em: 29 maio 2018.

JACOBI, D. F.; HABOWSKI, Adilson Cristiano; CONTE, Elaine. Do Caos ao Cosmos: a metamorfose do aprender. Revista Diálogos (RevDia), v. 6, n. 1, p. 7-23, jan.-abr., 2018. Disponível em: 〈http://periodicoscientificos.ufmt.br/ojs/index.php/revdia/article/view/5479/pdf> Acesso em: 30 maio 2018.

LIBÂNEO, José Carlos. Didática. São Paulo: Editora Cortez, 1994.

MACHADO, D. F; HABOWSKI, Adilson Cristiano; CONTE, Elaine. Perspectivas entre educação, sociabilidades e redes. Anais do Congresso Latino-Americano de Gênero e Religião. São Leopoldo: EST, v. 5, 2017, p. 685-700. Disponível em: <http://anais.est.edu.br/index.php/genero/article/view/871/565> Acesso: 28 maio 2018.

SAVIANI, Demerval. História das ideias pedagógicas no Brasil. Campinas: Autores Associados, 2007.

THEUNISSEN, Michael. Negativität bei Adorno. In: FRIEDEBURG, Ludwig von.; HABERMAS, Jürgen. (Hrsg.). Adorno-Konferenz. Frankfurt/Main: Suhrkamp, 1983.

TÜRCKE, Christoph. Sociedade excitada: filosofia da sensação. Campinas: Editora da Unicamp, 2010.

ZUIN, Vânia Gomes.; ZUIN, Antonio. Álvaro Soares. Professores, tecnologias digitais e a distração concentrada. Educar em Revista, Curitiba, n. 42, p. 213-228, 2011. Disponível em:< http://www.scielo.br/scielo.php?script=sci_arttext\&pid=S0104-40602011000500014> Acesso em: 27 maio 2018.

ZUIN, Antonio Álvaro Soares. A autoridade pedagógica em tempos de cultura digital. Educação e Filosofia, Uberlândia, v. 29, n. 58, p. 745 - 769, 2015. Disponível em: < http://www.seer.ufu.br/index.php/EducacaoFilosofia/article/view/26187/18047> Acesso em: 28 maio 2018.

\footnotetext{
${ }^{\text {i }}$ Professora do Programa de Pós-Graduação em Educação da Universidade La Salle - UNILASALLE/Canoas. Doutora em Educação (UFRGS). Líder do Núcleo de Pesquisas sobre Tecnologias na Educação - NETE/CNPq e membro do Grupo de Estudos sobre Filosofia da Educação e Formação de Professores - GEFFOP/CNPq.

ii Mestrando em Educação da Universidade La Salle. Bolsista da CAPES e Membro do grupo de pesquisa NETE/UNILASALLE/CNPq.
} 